\title{
UJI KATALITIK HERBAL EKSTRAK DAUN SELASIH SEBAGAI PENYEMBUHAN FLU
}

\author{
Rosa Karlina*1 \\ ${ }^{1}$ Pendidikan Kimia,FMIPA, Universitas Negeri Padang, Indonesia \\ *Email: rosakarlina13@gmail.com
}

\begin{abstract}
Abstrak. Studi ini bertujuan untuk membuat ekstrak air daun selasih untuk penyembuhan flu dan demam. Metode yang digunakan adalah eksperimen dan uji aktivitas katalik secara langsung. Tahapan pertama yang di lakukan adalah pembuatan ekstrak dari daun selasih. Uji aktivitas langsung dilakukan dengan variasi pemakaian setiap 15 menit sehari. Hasil eksperimen membuktikan bahwa remasan daun selasih dapat menyembuhkan flu dan hidung tersumbat. Kondisi optimum terhadap ekstrak daun selasih dapat dilihat 1 hari dengan berkali-berkali pemakaian. Penyembuhan ini di duga karena aktivitas/zat aktif yaitu asam fenolat yang memiliki aktivitas anti bakteri, anti inflamasi, anti kanker, dan anti virus.
\end{abstract}

Keywords : daun selasih, katalitik, flu, asam fenolat.

\section{Pendahuluan}

Reaksi- reaksi kimia(1)adalah suatu reaksi yang meyebabkan terjadinya suatu perubahan bentuk ke bentuk yang baru. Reaksi kimia (2)terjadi karena interaksi antara suatu senyawa(3)dengan senyawa lain yang menyebabkan membentuk suatu zat yang baru. Secara kualitatif(4)di amati dengan perubahan warna, suhu, endapan, dan lain-lainnya. Laju kecepatan suatu reaksi kimia(5) itu berbeda-beda tergantung suhu(6)dan kosentras(7).Reaksi-reaksi kimia bisa di percepat dengan penambahan suatu katalis. Katalis(8) ini berguna untuk mempercepat reaksi tanpa dan tidak ikut bereaksi. Pada akhir reaksi katalis ini terbentuk lagi.

Reaksi kimia penting karena dalam semua aspek(9) kehidupan terdapat reaksi kimia. Salah satu reaksi yang sering terjadi ialah reaksi yang terjadi didalam tubuh(10) manusia, yaitu ketika meminum obat-obatan(11) yang berfungsi untuk meredakan sakit. Sakit tersebut dikarena oleh suatu kontraksi di dalam tubuh, dimana tubuh sedang mengalami suatu kondisi yang kurang normal. Pemakaian obat yaitu berfungsi untuk meredakan, obat ini kan berinteraksi dengan sakit sehingga akan meredakan sakit. Didalam obat terdapat suatu katalik(12) yang berguna untuk mempercepat kerja obat di dalam tubuh. Obat yang sering digunakan oleh masyarakat adalah obat yang di beli di apotek dan warung. Padahal ada obat herbal yang dapat menyembuhkan sakit tanpa ada efek samping dan ketergantungan dalam penggunaannya. Salah satu obat herbal yang daun selasih(13) yang merupakan katalik alami(14).

Selasih yang mempunyai nama latin Ocimum basilicum(15)jenis tumbuhan obat keluarga(16)yang tumbuh di sekitar penggarakaran rumah. Selasih yang termasuk tumbuhan liar, mempunyai ciri-ciri mempunyai batang yang keras, warna daun hijau pucat, bijinya sering di gunakan sebagai campuran makanan dan minum. Selasih mempunyai multi khasiat yaitu asam fenolat(17)yang bersifat untuk anti kanker, anti bakteri dan virus digunakan untuk mengobati flu.

Flu(18)sering didapatkan pada musim panca roba. Flu yang di sebabkan oleh infeksi virus(19) ke dalam tubuh yang di salurkan melalui udara yang telah terkontaminasi(20)oleh orang kena flu. Biasanya gejala flu adalah sulitnya bernafas dan sakit di bagian kepala. Biasanya 
masyarakat di kenagarian abai, kec. Solok Selatan mengobati flu dengan menggunakan katalik alami(21)daun selasih yang di diambil ekstraknya dengan cara di remaskan dan campurkan dengan air kemudian di basuhkan ke kepala dan kening.

Orang- orang di Abai kec. Sangir batang Hari. Kec Solok Selatan sudah melakukan pengobatan iflu dengan ekstrak daun selasih sudah turun- terumurun. Nenek moyang mereka menggunakan daun selasih tersebut untuk pengobati flu sebelum ada obat-obat kimia. Di karenakan selasih ini banyak terdapat di perkarang rumah dan tidak susah dalam mengaplikasikannya. Dan juga daun selasih ini terbukti menyembuhkan flu hanya dalam rentang waktu beberapa jam dari pemakaian(22)(23)

\section{Metode}

Alat dan Bahan:

Peralatan yang di gunkan untuk melakukan percobaan adalah: mangkuk( melanine ), pisau ( ).

Bahan yang di gunakan adalah daun selasih, bawang putih, air (aqua) yang diambil di Jorong Aur Duri, Nagari Abai.

Prosedur Kerja

1. Penyiapan Sampel

Sampel diambil di Jorong Aur Duri, Nagari Abai, Kec. Sangir $\quad$ Batang Hari, $\quad$ Kab. Solok Selatan, Sumatera Barat.

Sampel di ambil di ambil sebanyak 3 tangkai atau sekitar 6 gram, kemudian sampel di cuci dengan menggunakan air sampai bersih.

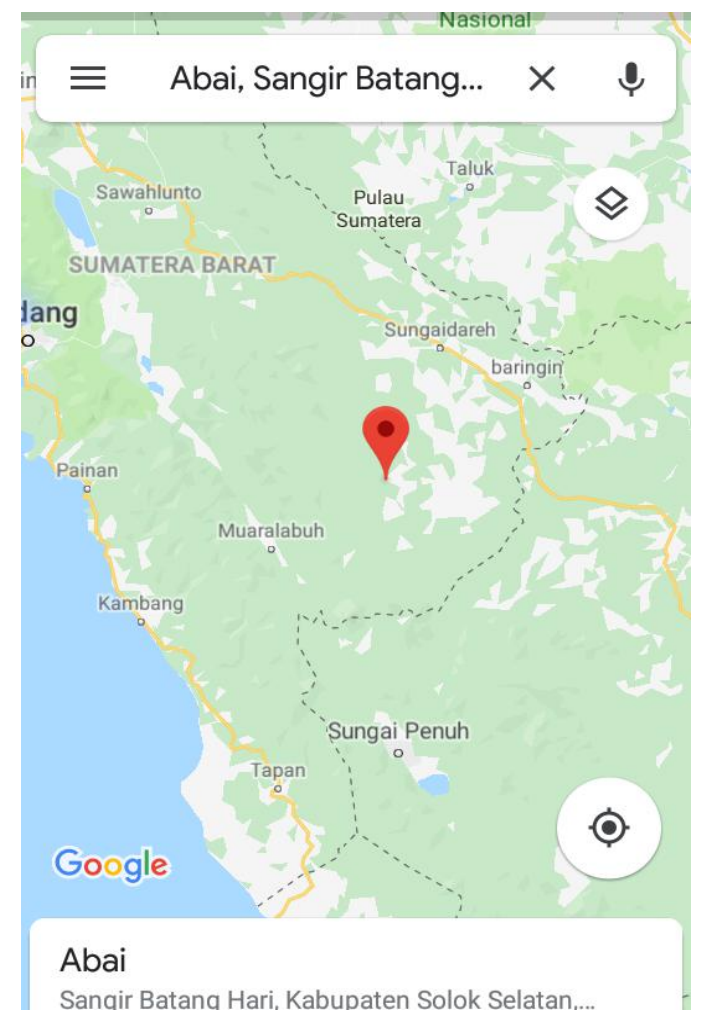


2. Pembuatan ekstrak Daun Selasih

Ekstrak di buat dengan cara meremas daun selasih sebanyak didalam mangkuk yang telah berisi air mineral sebanyak $220 \mathrm{ml}$ untuk memecahkan dinding sel agar zat hijau daunnya keluar kemuudian tambahkan irisan bawang putih.

3. Pengujian Ekstrak

Ekstrak yang telah jadi berikan kepada orang yang terkena flu dengan cara membalurkannya air ektrak selasih ke kepala dan kening dengan varian pemakaian berkali- kali pemakaian dalam sehari dalam rentang waktu 2 jam, 3 jam dan 4 jam. Hasil percobaan setelah dityakan kepada orang yang telah memakai obat tersebut. Hasil yang maksimal setelah rentang waktu 5 jam dari pemakaian obat tersebut.

Metode ini dapat dibuat menggunakan diagram alir sebagai berikut:

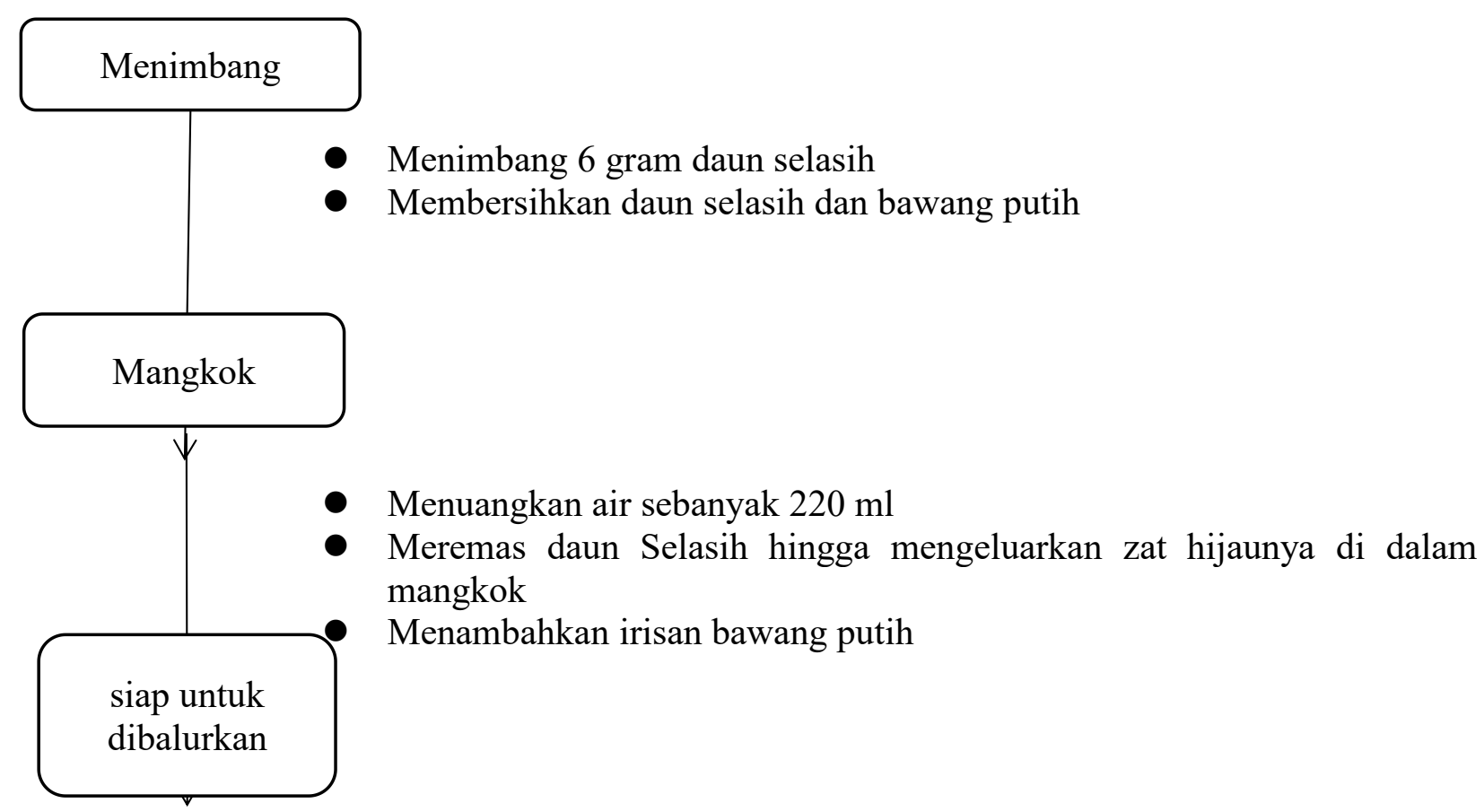

\section{Hasil dan Pembahasan Hasil}

1. Hasil Pembuatan

Hasil pembuatan air ekstrak di peroleh 1 mangkok. Pembuatan ini dengan 6 gram daun selasih dengan $220 \mathrm{ml}$ air. Hal ini dapat di lihat dari gambar di bawah ini : 


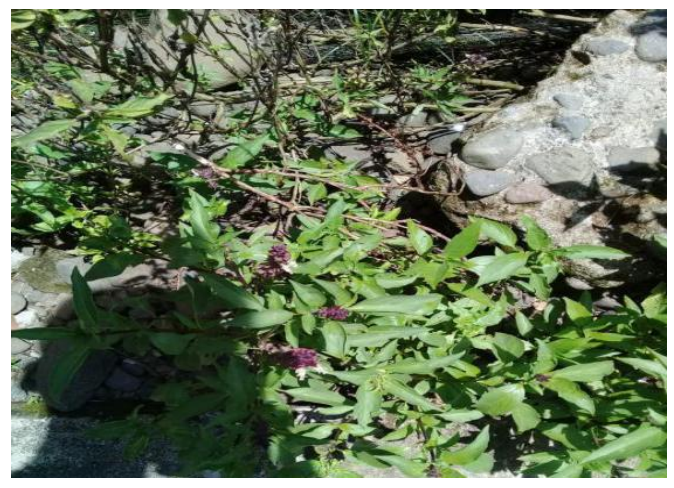

Persiapan sampel yaitu daun selasih

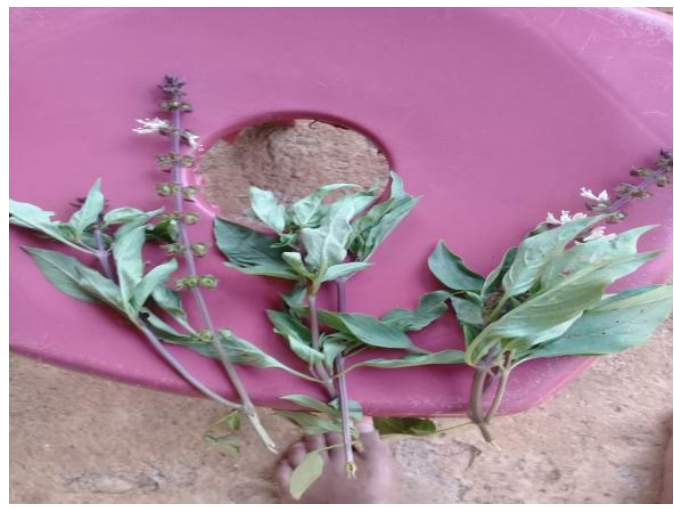

Mangambil sekitar 6 gram daun selasih

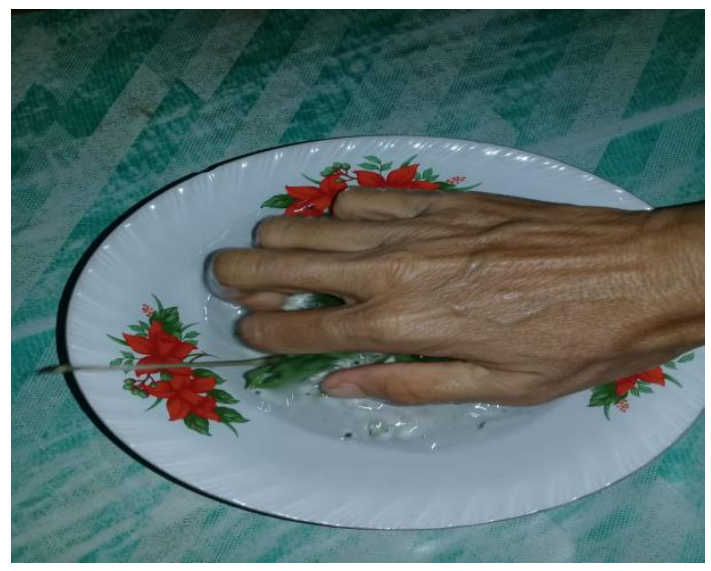

Meremas daun selasih hingga keluar zat hijau daunnya 


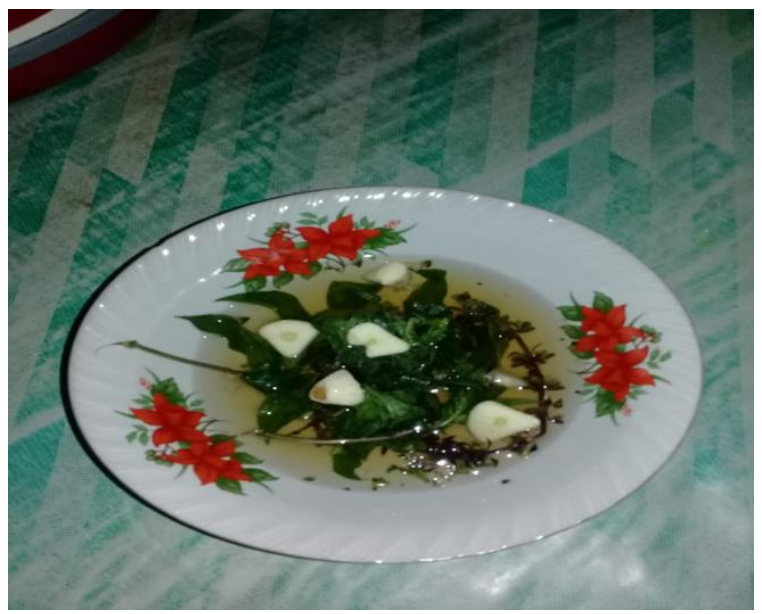

Menambahkan irisan bawang putih,

Obat flu dari ekstrak daun selasih siap di gunakan

2. Hasil Uji Coba

Pengujian di lakukan pada orang yang terkena penyakit flu ternyata berhasil meredakan flu, dapat di lihat dari tabel berikut:

\begin{tabular}{|c|l|l|}
\hline WAKTU & PEMAKAIAN & LEVEL BINTANG \\
\hline 2 JAM & 7 KALI & $* *$ \\
\hline 4 JAM & 14 KALI & $* * *$ \\
\hline 5 JAM & 17 KALI & $* * * * *$ \\
& & \\
\hline
\end{tabular}

kondisi Maksimum :*****

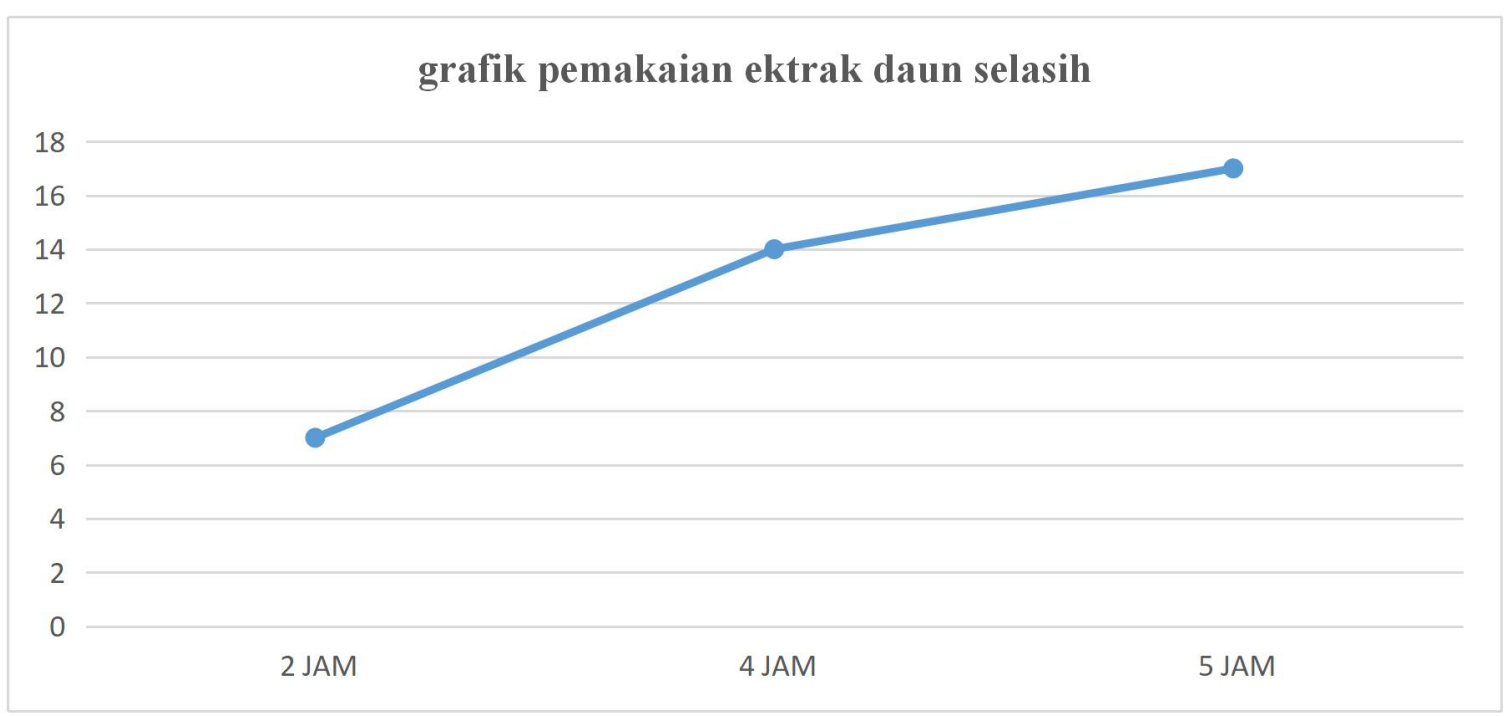




\section{Pembahasan}

1. Pembuatan

Pada saat pembuatan ekstrak kendala yang didapatkan yaitu mendapatkan daunny(24), walaupun pohon selasih(25)banyak tumbuh di pekarangan rumah penduduk tetapi dalam pengambilan daun nya, banyak dari pohon selasih itu yang telah tua(26), apabila batangnya telah tua, daunnya banyak yang gugur, karena umur dari batang selasih ini tidak lama, walaupun selasih adalah tumbuhan liar yang dapat di jumpai dimana saja, tetapi selasih hanya dapat hidup di konsisi tertentu yaitu pada tanda yang suhu, suhu yang normal yaitu pada iklim tropis dan pada daerah yang memiliki curah hujan yang tinggi.

Pengambilan daun yang di lakukan pada daun yang masih muda, karenapada daun yang muda senyawa asam fenolat banyak terdapat dari tumbuhan. Dan juga pada pengambilan sampel di usahakan mengambil bunga selasih karena selain di daun, di bunga juga terdapat senyawa(27)asam formiat.

2. Uji Coba

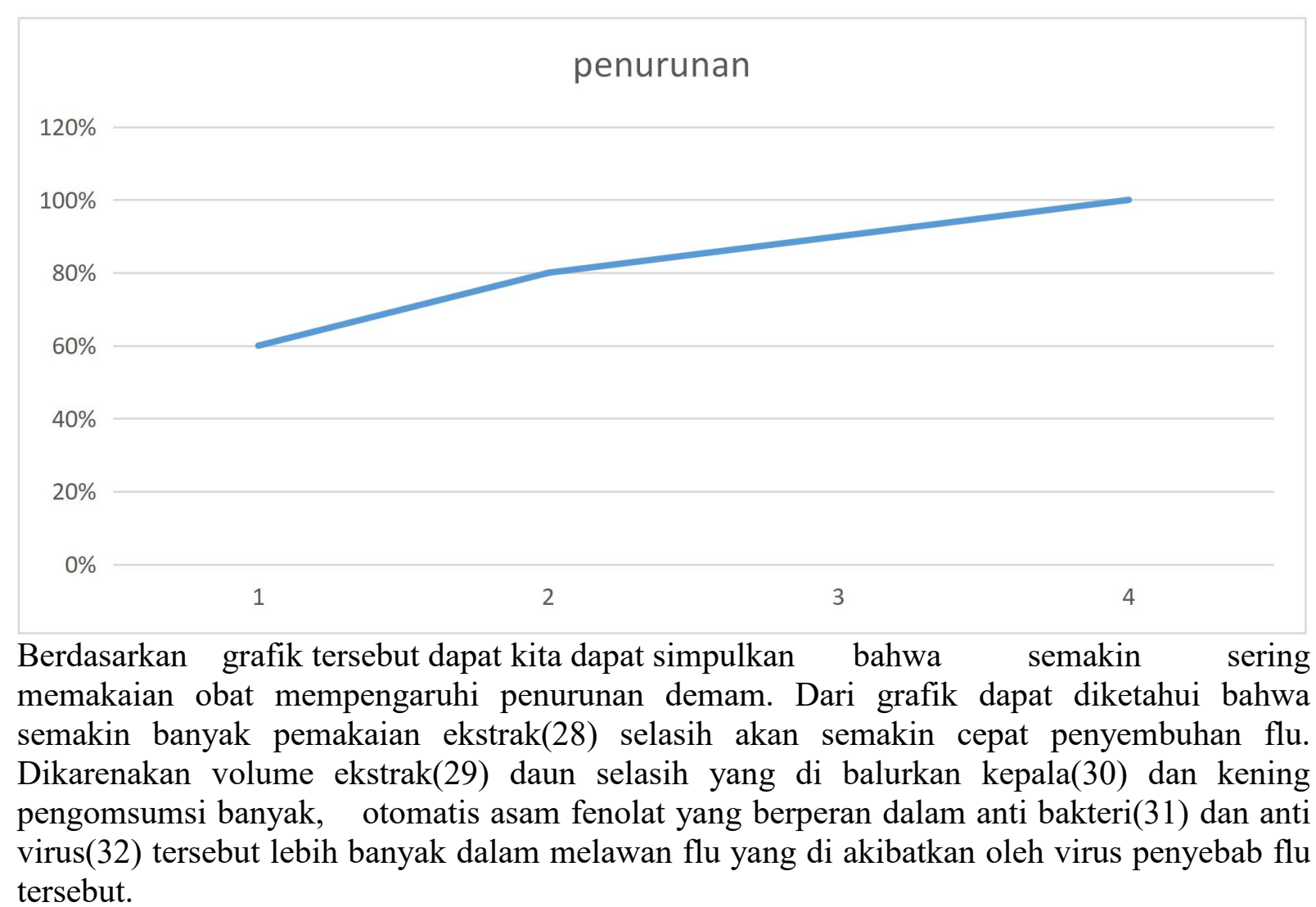
tersebut. 


\section{Interaksi}

Pada umumnya orang yang terkena flu yang di sebabkan oleh virus pada musim panca roba adalah orang yang mempunyai kondisi fisik(33) yang lemah dan pertahan tubuh yang lemah di pada saat terkontaminasi. Penurunan pertahan fisik tersebut di sebabkan oleh cuaca yang panas dan dingin yang bergantian secara ekstrim, dan orang terkena flu adalah orang tidak menjaga kesehatannya dengan tidak mengomsumsi air putih(34) dan di selingi minum vitamin dan buah-buahan yang mempunyai banyak elektron(35) sehingga apabila pertahan dirinya nya cukup virus akan diserang oleh antibodi(36) sehingga virus tidak menyebabkan penyakit bagi tubuh.

Daun Selasih Selasih yang mempunyai nama latin Ocimum basilicum yang berasal dari

Kingdom : Plantae

Divisio : Spermatophyta

Sub divisi : Angiospermae

Kelas : Dicotyledonae

Bangsa : Amaranthaceae

Suku : Lamiaciae (Labiatae)

Marga : $\underline{\text { Ocimum }}$

mempunyai senyawa yaitu asam fenolat yang berguna untuk antioksidan untuk pencegahan anti virus.<smiles>Oc1ccccc1</smiles>

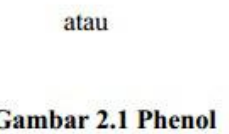<smiles>Oc1ccccc1</smiles>

Gambar 2.1 Phenol<smiles>O=C(O)c1cc(C2Oc3cc(O)cc(O)c3CC2O)cc(C2Oc3cc(O)cc(O)c3CC2O)c1O</smiles>

Gambar 2.2. Polifenol

Proses ekstrak(37)daun selasih ini sangat lah mudah yaitu dengan mengambil daun sebanyak 6 gram di nagari Abai, kec. Sangir batang hari, Kab. Solok Selatan, Sumatera Barat. Kemudian letakkan daun tersebut kedalam sebuah mangkok yang telah berisi air sebnyak 220 $\mathrm{ml}$ atau gelas air mineral. Kemudian daun tersebut di remas sehingga memecah(38) dinding sel hingga zat hijau daun(39) keluar yang di tandai dengan perubahan warna(40) pada air tersebut kemudian ada bau yang khas(41) yang tercium kemudian tambahkan dengan irisan bawang putih. Bawang putih mengandung zat yang berguna untuk membunuh bakteri atau anti bakteri memabantu katalik daun selasih dalam melawan virus yang menyebabkan flu.

Pemakaian ekstrak daun selasih ini terlihat hasil yang signifikan(43) setelah pemakian pertama di karenakan bau daun selasih yang khas akan melega kan pernapasan. Pada pemakaian rentang waktu 5 jam akan penderita flu akan sembuh total. 


\section{Kesimpulan}

1. Ekstrak Yang Di Buat Sebanyak 6 Gram Dalam 220 Ml Ekstraknya Sebanyak 220 Ml

2. Ekstrak Ini Dapat menyembuhkan Flu Dikarena Ada Senyawa Kataliknya Asam Formiat Yang Di Anti Virus Yang Akan Melawan Virus Penyebab Flu

3. Ekstrak Daun Selasih Yang Bekerja Secara Maksimum Pada Rentang Waktu 5 Jam Dari Pemakaian

\section{Referensi}

(1) Yeni, Yeni Dianita ( Fakultas Kesehatan Masyarakat, Universitas Ahmad Dahlan, Yogyakarta ), Djannah, Sitti Nur ( Fakultas Kesehatan Masyarakat, Universitas Ahmad Dahlan, Yogyakarta ), Nurani, Laela Hayu ( Fakultas Kesehatan Masyarakat, Universitas Ahmad Dahlan, Yogyakarta ).2010.UJI AKTIVITAS ANTIBAKTERI INFUSA DAUN SIRSAK (Annona muricata L.) SECARA in Vitro TERHADAP Staphylococcus aureus ATCC 25923 dan Escherichia coli ATCC 35218 SERTA PROFIL KROMATOGRAFI LAPIS TIPISNYA. Jurnal Kes Mas FKM UAD.Vol 4, No 3

(2) M., Sanjaya, H., \& Zainul, R. (2018, August 11). Characterization of napa soil and adsorption of $\mathrm{Pb}$ (II) from aqueous solutions using on column method. https://doi.org/10.31227/osf.io/t8fh9

(3) Hakimi, A., \& Zainul, R. (2019, January 31). Asam Arsenat (H3AsO4) : Analisis Molekular dan Karakteristik Senyawa. https://doi.org/10.31227/osf.io/e486z

(4) Setianto, S. (2017) "ANALISA KUANTITATIF CAMPURAN SENYAWA OKSIDA SEBAGAI DASAR IDENTIFIKASI KANDUNGAN BAHAN SUMBER DAYA ALAM Studi Kasus : Kandungan Mineral pada Pasir Besi di Pesisir Pantai Selatan, Jawa Barat", EKSAKTA: Berkala Ilmiah Bidang MIPA, 18(02), pp. 173-177. doi: 10.24036/eksakta/vol18-iss02/74

(5) Aumi, V., M., \& Zainul, R. (2018, August 25). Pengembangan Bentuk Lembar Kerja Siswa (LKS) untuk Aktivitas Kelas dan Laboratorium Berbasis Inkuiri Terbimbing pada Pokok Bahasan Laju Reaksi. https://doi.org/10.31227/osf.io/7rszp

(6) Syafei, N. (2018) "Riset Material ANALISA FENOMENA KOROSI PELAT PIPA BAJA KARBON API 5L-X65 DALAM LARUTAN 7900 ML AIR LAUT DAN 100 ML AMONIAK PADA KONDISI GAS CO2 DAN H2S JENUH PADA SUHU RUANG.”, EKSAKTA: Berkala Ilmiah Bidang MIPA, 19(1), pp. 7-13. doi: 10.24036/eksakta/vol19-iss1/83

(7) Tutuarima, T. (2017) "SIFAT FISIK DAN KIMIA MARMALADE JERUK KALAMANSI (Citrus microcarpa) : KAJIAN KONSENTRASI PEKTIN DAN SUKROSA Physical and Chemical Properties of Marmalade Citrus of Calamondin (Citrus microcarpa) : Study of Pectin and Sucrose Concentrations", EKSAKTA: Berkala Ilmiah Bidang MIPA, 18(02), pp. 164-172. doi: 10.24036/eksakta/vol18-iss02/73.

(8) Sanjaya, H. (2017) "DEGRADASI METHYLENE BLUE MENGGUNAKAN KATALIS ZnO-PEG DENGAN METODE FOTOSONOLISIS", EKSAKTA: Berkala Ilmiah Bidang MIPA, 18(02), pp. 21-29. doi: 10.24036/eksakta/vol18-iss02/45

(9) Zainul, R., \& Prima, C. B. (2018, December 9). TEKNOLOGI MATERIAL MAJU Prinsip Dasar dan Aspek Rekayasa. https://doi.org/10.31227/osf.io/p63wc 
(10)Anhar, A., Sumarmin, R., \& Zainul, R. (2016). Measurement of Glycemic Index of West Sumatera Local Rice Genotypes for Healthy Food Selection. Journal of Chemical and Pharmaceutical Research, 8(8), 1035-1040

(11)Desni, Fitriana ( Fakultas Kesehatan Masyarakat, Universitas Ahmad Dahlan, Yogyakarta ), Wibowo, Trisno Agung ( Fakultas Kesehatan Masyarakat, Universitas Ahmad Dahlan, Yogyakarta ), Rosyidah, . ( Fakultas Kesehatan Masyarakat, Universitas Ahmad Dahlan, Yogyakarta ).2011.HUBUNGAN PENGETAHUAN, SIKAP, PERILAKU KEPALA KELUARGA DENGAN PENGAMBILAN KEPUTUSAN PENGOBATAN TRADISIONAL DI DESA RAMBAH TENGAH HILIR KECAMATAN RAMBAH KABUPATEN ROKAN HULU, RIAUJurnal Kesehatan Masyarakat (Journal of Public Health)Jurnal Kesehatan Masyarakat (Journal of Public Health)Vol 5, No 3

(12)Sanjaya, H. (2018) "DEGRADASI METIL VIOLET MENGGUNAKAN KATALIS ZnO-TiO2 SECARA FOTOSONOLISIS", EKSAKTA: Berkala Ilmiah Bidang MIPA, 19(1), pp. 91-99. doi: 10.24036/eksakta/vol19-iss 1/131

(13)Shahabuddin, Shahabuddin.2011.EFEKTIVITAS EKSTRAK DAUN SELASIH (Ocimum Sp.) DAN DAUN WANGI (Melaleuca bracteata L.) SEBAGAI ATRAKTAN LALAT BUAH PADA TANAMAN CABAI AGROLAND.Vol 18, No 3.

DOI: http://dx.doi.org/10.22487/J.24077607.2011.v18.i3.3598

(14)Mulia, M. (2017) "ISOLASI KUMARIN DARI KULIT BUAH LIMAU SUNDAI (Citrus nobilis Lour)", EKSAKTA: Berkala Ilmiah Bidang MIPA, 18(02), pp. 137-145. doi: 10.24036/eksakta/vol18-iss02/70.

(15)Istimuyasaroh, M. Hadi, and U. Tarwotjo.2009. MORTALITAS DAN PERTUMBUHAN LARVA NYAMUK ANOPHELES ACONITUS KERENA PEMBERIAN EKSTRAK DAUN SELASIH OSCIMUM BASILICUM. Bioma : Berkala Ilmiah Biologi, vol. 11, no. 2, https://doi.org/10.14710/bioma.11.2.59-63

(16)Yanto Nugroho, Duta ( Universitas Ahmad Dahlan ), Noviyanto, Fiftin ( Universitas Ahmad Dahlan ).2003.MEMBANGUN SISTEM PEMBUATAN RESEP OBAT UNTUK MENCEGAH PEMALSUAN DENGAN TEKNIK CODE GENERATOR BERBASIS WEBJurnal Sarjana Teknik InformatikaVol 1, No 1

(17)Soetarno, Soediro ( Jurusan Farmasi FMIPA-ITB Bandung ), Suganda, Asep Gana ( Jurusan Farmasi FMIPA-ITB Bandung ), Sugihartina, Gantina ( Jurusan Farmasi FMIPA-ITB Bandung ) , Sukrasno, Sukrasno ( Jurusan Farmasi FMIPA-ITB Bandung ).2000.FLAVONOID DAN ASAM-ASAM FENOLAT DARI DAUN DEWA [GYNURA PROCUMBENS (LOUR.) MERR]Warta Tumbuhan Obat Indonesia.Vol 6, No 1

(18)Rachmawati, Tety ( Puslitbang Sistem dan Kebijakan Kesehatan, Surabaya ), Laksmiarti, Turniani ( Puslitbang Sistem dan Kebijakan Kesehatan, Surabaya ), Soenarsongko, Soenarsongko ( Dinas Kesehatan Provinsi Jawa Timur ).2008.HUBUNGAN KEKELUARGAAN DAN TINGGAL SERUMAH MERUPAKAN KARAKTERISTIK PENGAWAS MINUM OBAT YANG BERPENGARUH TERHADAP KETERATURAN MINUM OBAT PENDERITA TUBERKULOSIS PARU.Buletin Penelitian Sistem Kesehatan.Vol 11, No 3

(19)Susanti, R, Damajanti Soejoedono, Retno, Kade Mahardika, I Gusti Ngurah, Wibawan, I Wayan Teguh, Thenawidjaja Suhartono, Maggy.2003.PHYLOGENETIC AND ANTIGENIC STRUCTURE OF AVIAN INFLUENZA VIRUS OF H5N1 SUBTYPE ISOLATED FROM WATERFOWLS.Jurnal Veteriner Vol 9, No 3 
(20)Dinata, A. A., Rosyadi, A. M., Hamid, S., \& Zainul, R. (2018, October 15). A Review CHEMICAL VAPOR DEPOSITION:PROCESS AND APPLICATION. https://doi.org/10.31227/osf.io/yfeau

(21)Rizki Saputra, M. and Sumarmin, R. (2018) "PENGARUH EKSTRAK DAUN SIRIH MERAH (Piper crocatum Ruiz \& Pav.) TERHADAP GLUKOSA DARAH MENCIT (Mus musculus L.) JANTAN YANG DIINDUKSI SUKROSA”, EKSAKTA: Berkala Ilmiah Bidang MIPA, 19(1), pp. 43-55. doi: 10.24036/eksakta/vol19-iss1/124

(22) Yuliani, F., \& Zainul, R. (2018, November 13). Analisis Termodinamika Molekul Magnesium Sulphate (MgSO4). https://doi.org/10.31227/osf.io/uxz4y.

(23)Mawardi, M., Deyundha, D., \& Zainul, R. (2018, April). Characterization of PCC Cement by Addition of Napa Soil from Subdistrict Sarilamak 50 Kota District as Alternative Additional Material for Semen Padang. In IOP Conference Series: Materials Science and Engineering (Vol. 335, No. 1, p. 012034). IOP Publishing

(24)Setianto, S. (2017) "ANALISA KUANTITATIF CAMPURAN SENYAWA OKSIDA SEBAGAI DASAR IDENTIFIKASI KANDUNGAN BAHAN SUMBER DAYA ALAM Studi Kasus : Kandungan Mineral pada Pasir Besi di Pesisir Pantai Selatan, Jawa Barat", EKSAKTA: Berkala Ilmiah Bidang MIPA, 18(02), pp. 173-177. doi: 10.24036/eksakta/vol18-iss02/74

(25)Alfionita, T., \& Zainul, R. (2019, January 29). Calcium Chloride (CaCl2) : Characteristics and Molecular Interaction in Solution. https://doi.org/10.31227/osf.io/m37xj

(26)Chatri, M., Mansyurdin, M., Bakhtiar, A. and Adnadi, P. (2017) "PERBANDINGAN KOMPONEN MINYAK ATSIRI ANTARA DAUN MUDA DAN DAUN DEWASA PADA HYPTIS SUAVEOLENS (L.)POIT”, EKSAKTA: Berkala Ilmiah Bidang MIPA, 18(02), pp. 1-12. doi: 10.24036/eksakta/vol18-iss02/41.

(27)Sumarmin, R. (2018) "Pengaruh Ekstrak Kulit Buah Manggis (Garcinia mangostana L.) terhadap Histologis Pankreas Mencit (Mus musculus L. Swiss Webster) yang Diinduksi Sukrosa", EKSAKTA: Berkala Ilmiah Bidang MIPA, 19(1), pp. 100-112. doi: 10.24036/eksakta/vol19-iss 1/123

(28)Zainul, R. (2018, August 16). Design and Modification of Copper Oxide Electrodes for Improving Conversion Coefficient Indoors Lights (PV-Cell) Photocells. https://doi.org/10.31227/osf.io/pgn84

(29)Rizki Saputra, M. and Sumarmin, R. (2018) "PENGARUH EKSTRAK DAUN SIRIH MERAH (Piper crocatum Ruiz \& Pav.) TERHADAP GLUKOSA DARAH MENCIT (Mus musculus L.) JANTAN YANG DIINDUKSI SUKROSA", EKSAKTA: Berkala Ilmiah Bidang MIPA, 19(1), pp. 43-55. doi: 10.24036/eksakta/vol19-iss 1/124.

(30)Febriani, S. S., Yolanda, T., Arianti, V. A., \& Zainul, R. (2018, October 12). A Review Solid Stated : Principles and Methode. https://doi.org/10.31227/osf.io/7us4x

(31)Yeni, Yeni Dianita ( Fakultas Kesehatan Masyarakat, Universitas Ahmad Dahlan, Yogyakarta ), Djannah, Sitti Nur ( Fakultas Kesehatan Masyarakat, Universitas Ahmad Dahlan, Yogyakarta ), Nurani, Laela Hayu ( Fakultas Kesehatan Masyarakat, Universitas Ahmad Dahlan, Yogyakarta ).2013. UJI AKTIVITAS ANTIBAKTERI INFUSA DAUN SIRSAK (Annona muricata L.) SECARA in Vitro TERHADAP Staphylococcus aureus ATCC 25923 dan Escherichia coli ATCC 35218 SERTA PROFIL KROMATOGRAFI LAPIS TIPISNYA. Jurnal Kesehatan Masyarakat (Journal of Public Health). Vol 4, No 3

(32)Mambang, D. Elysa Putri (Program Studi Magister Farmasi Fakultas Farmasi, Universitas Sumatera Utara, Medan), Rosidah, (Departemen Biologi Fakultas 
Matematika dan Ilmu Pengetahuan Alam, Universitas Sumatera Utara)-,Suryanto, dwi (Departemen Biologi Fakultas Matematika dan Ilmu Pengetahuan Alam, Universitas Sumatera Utara).2014.AKTIVITAS ANTIBAKTERI EKSTRAK TEMPE TERHADAP BAKTERI Bacillus subtilis DAN Staphylococcus aureus [Antibacterial Activity of Tempe Extracts on Bacillus subtilis and Staphylococcus aureus

Jurnal Teknologi dan Industri Pangan.Vol 25, No 1

(33)chaidir, z., Zainul, R., Nurakhbari, D., \& Salim, M. (2018, July 29). Optimization of Spirulina Platensis Culture for Antioxidant Production. https://doi.org/10.17605/OSF.IO/FD6E4

(34)chaidir, z., Zainul, R., Nurakhbari, D., \& Salim, M. (2018, July 29). Optimization of Spirulina Platensis Culture for Antioxidant Production. https://doi.org/10.17605/OSF.IO/FD6E4

(35)Sari, E. S. J., \& Zainul, R. (2019, January 31). Nitrogen Triflorida (NF3) : Termodinamika dan Transpor Elektron NF3. https://doi.org/10.31227/osf.io/3nzrh

(36)Horiza, H., Azhar, M. and Efendi, J. (2017) "EKSTRAKSI DAN KARAKTERISASI INULIN DARI UMBI DAHLIA (Dahlia sp.L) SEGAR DAN DISIMPAN", EKSAKTA: Berkala Ilmiah Bidang MIPA, 18(01), pp. 31-39. doi: 10.24036/eksakta/vol18-iss01/14.

(37)Hakimi, A., \& Zainul, R. (2019, January 31). Asam Arsenat (H3AsO4) : Analisis Molekular dan Karakteristik Senyawa. https://doi.org/10.31227/osf.io/e486z

(38)Zainul, R. (2018, August 16). Determination of the half-life and the quantum yield of $\mathrm{ZnO}$,semiconductor photocatalyst in humic acid. https://doi.org/10.31227/osf.io/e8a9x

(39)Dhianawaty, Diah ( Departemen Biokimia Fakultas Kedokteran Universitas Padjadjaran Bandung, jalan Raya Bandung Sumedang km 21 ), Panigoro, Ramdan ( Departemen Biokimia Fakultas Kedokteran Universitas Padjadjaran Bandung, jalan Raya Bandung Sumedang km 21 ), Surialaga, Samsudin ( Departemen Biokimia Fakultas Kedokteran Universitas Padjadjaran Bandung, jalan Raya Bandung Sumedang km 21 ), Purushothman, Pricilla ( Departemen Biokimia Fakultas Kedokteran Universitas Padjadjaran Bandung, jalan Raya Bandung Sumedang km 21 ).2012. METODE CEPAT IDENTIFIKASI FLAVONOID DARI DAUN OCIMUM SANCTUM L. (SELASIH).Majalah Kedokteran Bandung Vol 44, No 1

(40)Amananti, W. (2017) “ANALISIS MIKROSTRUKTUR LAPISAN TIPIS TiO2:ZnO YANG DIDEPOSISIKAN DIATAS SUBTRAT KACA DENGAN METODE SPRAY COATING UNTUK DEGRADASI LIMBAH ZAT WARNA", EKSAKTA: Berkala Ilmiah Bidang MIPA, 18(02), pp. 210-215. doi: 10.24036/eksakta/vol18-iss02/81.

(41)Yanto Nugroho, Duta ( Universitas Ahmad Dahlan ), Noviyanto, Fiftin ( Universitas Ahmad Dahlan ).2013. MEMBANGUN SISTEM PEMBUATAN RESEP OBAT UNTUK MENCEGAH PEMALSUAN DENGAN TEKNIK CODE GENERATOR BERBASIS WEB. Jurnal Sarjana Teknik Informatika.Vol 1, No 1

(42)Lubis, A. P., \& Zainul, R. (2018, November 5). Interaksi Molekuler Amonium Hidroksida. https://doi.org/10.31227/osf.io/jht3b 